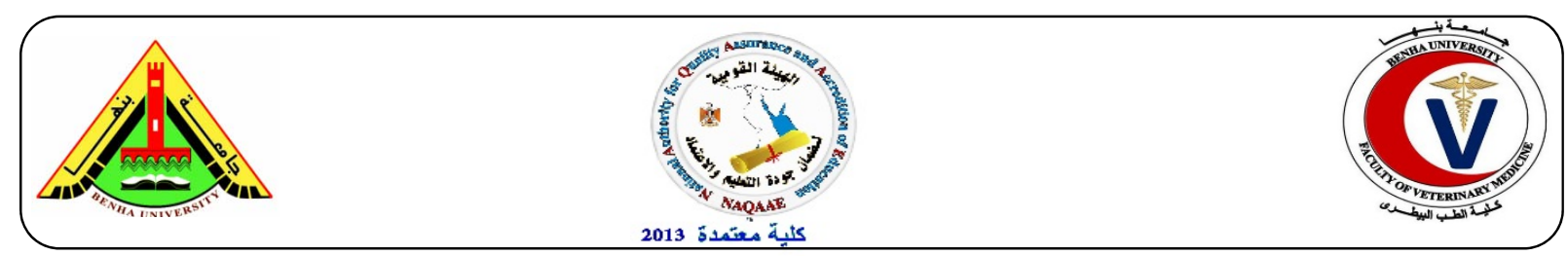

\title{
Ciprofloxacin residues in chicken and turkey carcasses
}

\author{
Faten, S. Hasanen ${ }^{a}$, Mousa, M. Mohammed ${ }^{b}$, Mahomud, A. H.c, Wafaa, M.M. Hassand and \\ Fatma, H. Amro ${ }^{\text {d. }}$ \\ ${ }^{\text {a }}$ Head of Department of Food control, Faculty of Veterinary Medicine, Benha University, Egypt. \\ ${ }^{b}$ Vice dean for Education and Student Affairs, Faculty of Veterinary Medicine, Adfina, Egypt. \\ ${ }^{c}$ Department of Biotechnology, Animal Health Research Institute, Dokki, Egypt. \\ ${ }^{d}$ Reference Laboratory for Veterinary Quality Control on Poultry Production, Animal Health Research Institute, Dokki,
}

\begin{abstract}
A B S T R A C T
Ciprofloxacin residues were detected in chicken and turkey tissues "thigh, breast, liver and kidney" by using HPLC. Results reflected a significant difference variation among kidney, liver, breast and thigh in examined chicken and turkey samples as $p$ values $<0.05$ indicating that kidney and liver are the site of accumulation of ciprofloxacin residues The highest residual level of ciprofloxacin found in kidney then liver Whereas the lowest concentrations were found in breast then thigh muscles. The means average of ciprofloxacin residues in examined chicken samples in kidney, liver, breast and thigh respectively, were $316+/-26.4 \mu \mathrm{g} / \mathrm{kg}, 211.1+/-20.6 \mu \mathrm{g} / \mathrm{kg}, 131.7+/-25.2 \mu \mathrm{g} / \mathrm{kg}$ and $92.11+/-30.1 \mu \mathrm{g} / \mathrm{kg} ; \mathrm{on}$ the other side the means for turkey samples were $291.9+/-29.9 \mu \mathrm{g} / \mathrm{kg}, 205.7+/-23 \mu \mathrm{g} / \mathrm{kg}, 119.2+/-12.5 \mu \mathrm{g} / \mathrm{kg}$ and $83.2+/-$ $19.6 \mu \mathrm{g} / \mathrm{kg}$ respectively; By Using of different heat treatment processes, Ciprofloxacin residues are heat stable compounds as they couldn't be degraded by any cooking methods except microwaving at $800 \mathrm{~W}$ with one spoonful of sunflower oil for 15-20 minutes for muscles and 3-5 minutes for liver and kidney, Also freezing for 1 month at $-20 c^{\circ}$ could degrade ciprofloxacin to its metabolites at levels lower than permissible limits but not to Un detectable levels.
\end{abstract}

key words: Residues -Ciprofloxacin -Poultry- Turkeys -HPLC.

(http://www.bvmj.bu.edu.eg)

(BVMJ-31(2): 136-143, 2016)

\section{INTRODUCTION}

Accumulation of drug residues in animal tissues poses risks to human health and may result from blind of veterinary drugs without respect to their withdrawal period (Posyniak et al., 2001). Ciprofloxacin is Fluroquinolones antibiotic and the main metabolite of Enrofloxacin (European Agency for the Evaluation of Medicinal (EMEA), 1998). Fluroquinolones are the main cause of bacterial resistance, whereas occurrence of their residues in edible tissues, leads to transmission of resistant bacteria, while if these residues were beyond the acceptable levels, their metabolites caused harmful effects on the human health (Gouvêa et al., 2015). Quinolones" enrofloxacin and ciprofloxacin" residues had high heat stability, heat treatment is not effective on them (Botsoglou and Fletouris, 2001). Controlling of ciprofloxacin residues by freezing at $-18 \mathrm{c}{ }^{\circ}$ had a positive effect on degradation of its residues, (Aboul EL, 2006). European Agency for the Evaluation of Medicinal (EMEA) (2002) set a maximum permissible limit "MRL" for the sum of enrofloxacin and ciprofloxacin residues in poultry tissues as
$100 \mu \mathrm{g} / \mathrm{kg}, 200 \mu \mathrm{g} / \mathrm{kg}$ and $300 \mu \mathrm{g} / \mathrm{kg}$ in muscles, liver and kidney respectively.

\section{Material and Methods}

\subsection{Drugs:}

Ciprofloxacin standard were obtained from Sigma Aldrich.

\subsection{Field survey tissue sampling plane}

A grand total of 120 fresh chicken and turkey tissue samples "each of 60 samples" represented as 15 of each tissue thigh, breast, liver and kidney. They were collected from special abattoir in Qalyiobyam and Giza governorates. Each sample was represented by 20 grams for fresh samples. The samples were placed in plastic bags then transferred to the laboratory without undue delay in an ice box.

\subsection{Apparatus and Equipment}

High performance liquid chromatography (HPLC) Agilent Series 1200, Analytical column 
C18, Electronic digital balance, mincer, Shaker, sonicator, High speed cooling centrifuge and acrodiscs $(0.45 \mu \mathrm{m})$.

\subsection{Chemical reagents}

Deionized water (HPLC-grade). Acetonitrile, Ethanol "HPLC grade" were obtained from sigma alderish, acetic acid diluted in water. $5 \%(\mathrm{w} / \mathrm{v})$ of trichloro-acetic acid (TCA).

\subsection{Analytical procedures}

\subsubsection{Preparation of samples for analysis}

The chicken and turkey samples were homogenized and frozen till the time of analysis at $-20^{\circ} \mathrm{c}$ in the dark.

\subsubsection{Extraction of Ciprofloxacin}

Extraction of Ciprofloxacin residues from Chicken and turkey tissues was done according to Verdon et al. (2004).

\subsubsection{Liquid chromatography operating conditions}

Injection volume, $25 \mu \mathrm{l}$; flow rate, $1 \mathrm{~mL} / \mathrm{min}$; $\mathrm{UV}$ at wave length, $280 \mathrm{~nm}$; column C18 Teknorama $(250 * 4.6 \mathrm{~mm} ; 5 \mu \mathrm{m})$ column temperature, $50^{\circ} \mathrm{c}$; stop time, $25 \mathrm{~min}$; post time, 1 min. Mobile phase: isocratic mode $50 \mathrm{ml} / 1$ acetic acid: acetonitrile: methanol (900:50:50). According to (Kameri et al., 1998).

\subsection{Experimental design}

\subsubsection{Control of antibiotic residues hazards using different heat treatment processes and freezing.}

\subsubsection{Preparation of samples}

Three samples had higher permissible limits of each tissue "breast, thigh, liver and kidney "of chicken and turkeys were prepared for different cooking procedures.

\subsubsection{Cooking by boiling}

Slices of chicken\& turkey samples "thigh and breast, liver and kidney" were placed in boiling water and boiled for 15-30 minutes for muscles, 10 minutes for liver and kidney.

\subsubsection{Cooking by grilling}

Slices of chicken \& turkey samples "thigh and breast, liver and kidney" were placed in pan with few drops of corn oil and grilled for 10 minutes for all examined samples at $170-180 \mathrm{c}^{\circ}$

\subsubsection{Cooking by roasting}

Slices of chicken \& turkey samples "thigh, breast, liver and kidney" were roasted at $60-65 \mathrm{c}^{\circ}$ for 15-30 minutes for muscles, 10 minutes for liver and kidney.

\subsubsection{Cooking by microwaving}

Slices of chicken \& turkey samples "thigh, breast, liver and kidney" were micro waved at 800 W with one spoonful of sunflower oil for 15-20 minutes for muscles, 3-5 minutes for liver and kidney. The cooked meat had a "well done" appearance on the outside.

\subsubsection{Freezing}

Slices of chicken \& turkey samples "thigh, breast, liver and kidney" were preserved in deep freezer at $-20{ }^{\circ} \mathrm{C}$ for one month.

\subsection{Statistical Analysis}

The obtained results were statistically evaluated by application of Analysis of Variance (ANOVA) test according to Feldman et al. (2003).

\section{Results}

It is evident from results in table (1) that the average means of ciprofloxacin residues in examined chicken samples were higher in kidney than in liver, Whereas the lower concentrations were recorded in breast and thigh muscles. These results showed a significant difference among the examined samples. The acceptability of examined chicken samples " thigh, breast, liver and kidney " depended on their levels of ciprofloxacin residues as shown in table (1). According to EMEA, (2002) that established the maximum permissible limit of ciprofloxacin in chicken tissues as $100 \mu \mathrm{g} / \mathrm{kg}$ in muscles, $200 \mu \mathrm{g} / \mathrm{kg}$ in liver and $300 \mu \mathrm{g} / \mathrm{kg}$ in kidney. The acceptability of chicken thigh samples was 3 of 7 samples $(42.8 \%)$ had exceeded the (MRL), while 4 of 7 samples (75.1\%) were within the permissible limit (PL). Whereas in breast. Unaccepted breast samples were 4 of 9 samples (44.4\%) had exceeded the (MRL), while 5 of 9 samples $(55.6 \%)$ were within the(PL). While in chicken liver samples 8 of 13 samples $(61.5 \%)$ were unaccepted as they exceeded the (MRL), while 5 of 13 samples $(38.5 \%)$ were within the (PL). This obtained results revealed the acceptability of kidneys samples as 10 of 13 samples $(76.9 \%)$ exceeded the (MRL), while 3 of 13 samples (23.1\%) were within the (PL). 
Faten Hasanein et al. (2016). BVMJ-31(2): 136-143

Table (1) Statistical analytical results of ciprofloxacin residues $(\mu \mathrm{g} / \mathrm{kg})$ in examined chicken samples $(\mathrm{n}=15)$.

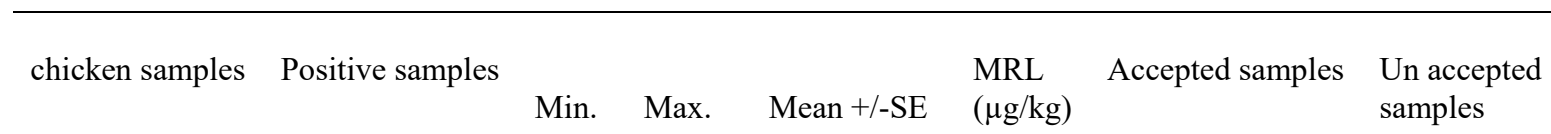

\begin{tabular}{|c|c|c|c|c|c|c|c|c|c|c|}
\hline & No. & $\%$ & & & & & No. & $\%$ & No. & $\%$ \\
\hline Thigh & 7 & 46.7 & 12.5 & 200.13 & $92.11+/-30.1$ & 100 & 4 & 75.1 & 3 & 42.8 \\
\hline Breast & 9 & 60 & 24.4 & 220.2 & $131.7+/-25.2$ & 100 & 5 & 55.6 & 4 & 44.4 \\
\hline Liver & 13 & 86.7 & 96.33 & 300.27 & $211.1+/-20.6$ & 200 & 5 & 38.5 & 8 & 61.5 \\
\hline Kidney & 13 & 86.7 & 109.3 & 400 & $316+/-26.4$ & 300 & 3 & 23.1 & 10 & 76.9 \\
\hline
\end{tabular}
the (MRL) established by EMEA, (2002) as $100,200,300 \mu \mathrm{g} / \mathrm{kg}$ in muscles, liver and kidneys respectively.

Table (2): Statistical analytical results of ciprofloxacin residues $(\mu \mathrm{g} / \mathrm{kg})$ in examined turkey samples $(\mathrm{n}=15)$.

\begin{tabular}{lcccccccccc}
\hline turkey’s samples & \multicolumn{3}{l}{ Positive samples } & & & & \multicolumn{2}{c}{$\begin{array}{c}\text { MRL } \\
(\mu \mathrm{g} / \mathrm{kg})\end{array}$} \\
& No. & $\%$ & Min. & Max. & Mean $+/$-SE & & No. & $\%$ & No. & $\%$ \\
\hline Thigh & 9 & 60 & 12.25 & 162.57 & $83.2+/-19.6$ & 100 & 6 & 66.7 & 3 & 33.3 \\
Breast & 11 & 73.3 & 65 & 183.19 & $119.2+/-12.5$ & 100 & 6 & 54.5 & 5 & 45.5 \\
Liver & 12 & 80 & 74.52 & 293.14 & $205.7+/-23$ & 200 & 5 & 41.7 & 7 & 58.3 \\
Kidney & 12 & 80 & 76.45 & 390 & $291.9+/-29.9$ & 300 & 4 & 33.3 & 8 & 66.7 \\
\hline
\end{tabular}


Table (3): Effect of some heat treatments on means of ciprofloxacin residues $(\mu \mathrm{g} / \mathrm{kg})$ in the examined samples of chicken tissues ( $\mathrm{n}=3)$.

\begin{tabular}{|c|c|c|c|c|c|c|c|c|c|c|c|}
\hline $\begin{array}{l}\text { Chicken } \\
\text { tissues }\end{array}$ & Raw & After boiling & $\mathrm{R} \%$ & $\begin{array}{l}\text { After } \\
\text { grilling }\end{array}$ & $\mathrm{R} \%$ & After roasting & $\mathrm{R} \%$ & After microwaving & $\mathrm{R} \%$ & $\begin{array}{l}\text { Freezing } \\
\text { After } 1 \\
\text { month at - } \\
20 c^{\circ}\end{array}$ & $\mathrm{R} \%$ \\
\hline Thigh & 193.7 & 193.7 & & 193.7 & & 193.7 & & 4.3 & 97.8 & 6.8 & 96.5 \\
\hline Breast & 204.2 & 204.2 & & 204.2 & & 204.2 & & 6.5 & 96.8 & 8.2 & 96 \\
\hline Liver & 292.54 & 292.54 & \multirow{2}{*}{$\begin{array}{l}0 \\
\frac{\pi}{\mathbb{I}} \\
\underset{N}{N}\end{array}$} & 292.54 & \multirow{2}{*}{$\begin{array}{l}0 \\
\frac{\alpha}{T} \\
\frac{1}{N}\end{array}$} & 292.54 & \multirow{2}{*}{$\begin{array}{l}\stackrel{0}{\frac{\pi}{N}} \\
\frac{1}{N}\end{array}$} & 20 & 93.2 & 19.8 & 93.2 \\
\hline Kidney & 390.13 & 390.13 & & 390.13 & & 390.13 & & 28.3 & 92.7 & 27.7 & 92.9 \\
\hline
\end{tabular}

$* \mathrm{R} \%$ : reduction $\%$.

Table (4): Effect of some heat treatment on means of ciprofloxacin residues $(\mu \mathrm{g} / \mathrm{kg})$ in the examined samples of turkey tissues ( $\mathrm{n}=3)$.

\begin{tabular}{|c|c|c|c|c|c|c|c|c|c|c|c|}
\hline $\begin{array}{c}\text { Turkeys } \\
\text { tissues }\end{array}$ & Raw & After boiling & $\mathrm{R} \%$ & After grilling & $\mathrm{R} \%$ & After roasting & $\mathrm{R} \%$ & After microwaving & $\mathrm{R} \%$ & $\begin{array}{c}\text { Freezing } \\
\text { after } 1 \text { month at } 20 c^{\circ}\end{array}$ & $\mathrm{R} \%$ \\
\hline Thigh & 151.7 & 151.7 & & 151.7 & & 151.7 & & 3 & 98 & 5.6 & 96.3 \\
\hline Breast & 170.4 & 170.4 & & 170.4 & & 170.4 & & 3.9 & 97.7 & 6.9 & 96 \\
\hline Liver & 282.48 & 282.48 & 0 & 282.48 & 0 & 282.48 & 0 & 17.6 & 93.8 & 15.7 & 94.4 \\
\hline Kidney & 373.4 & 373.4 & $\frac{n}{N}$ & 373.4 & $\frac{v}{N}$ & 373.4 & $\frac{v}{N}$ & 24.6 & 93.4 & 23.2 & 93.8 \\
\hline
\end{tabular}


Figure (1): calibration curve of ciprofloxacin residues by HPLC.

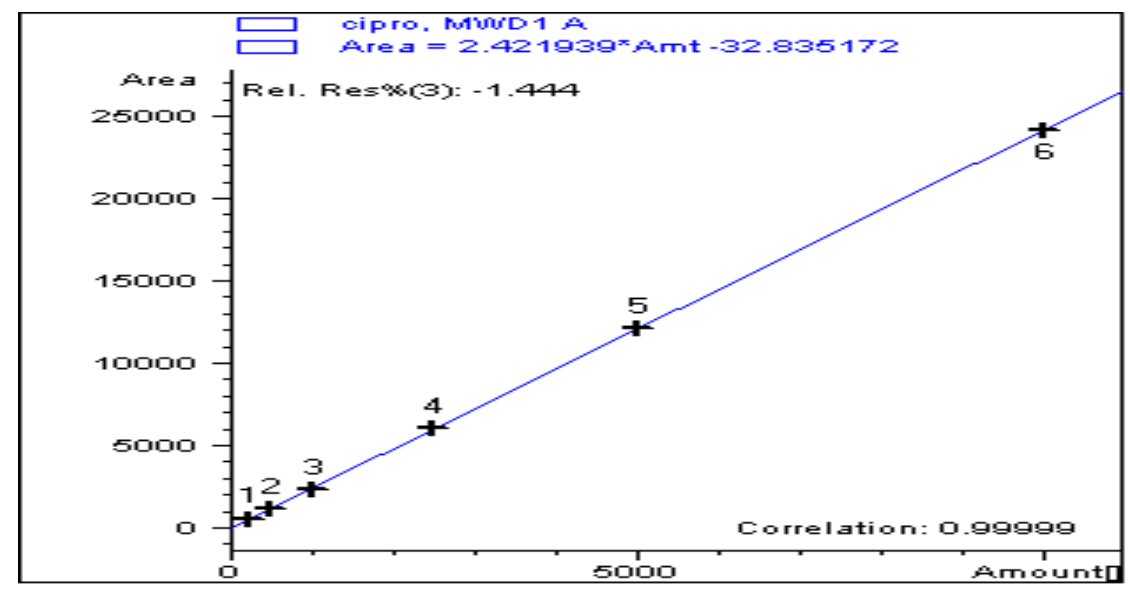

Figure (2): chromatograms of ciprofloxacin standards $1000 \mu \mathrm{g} / \mathrm{kg}$.

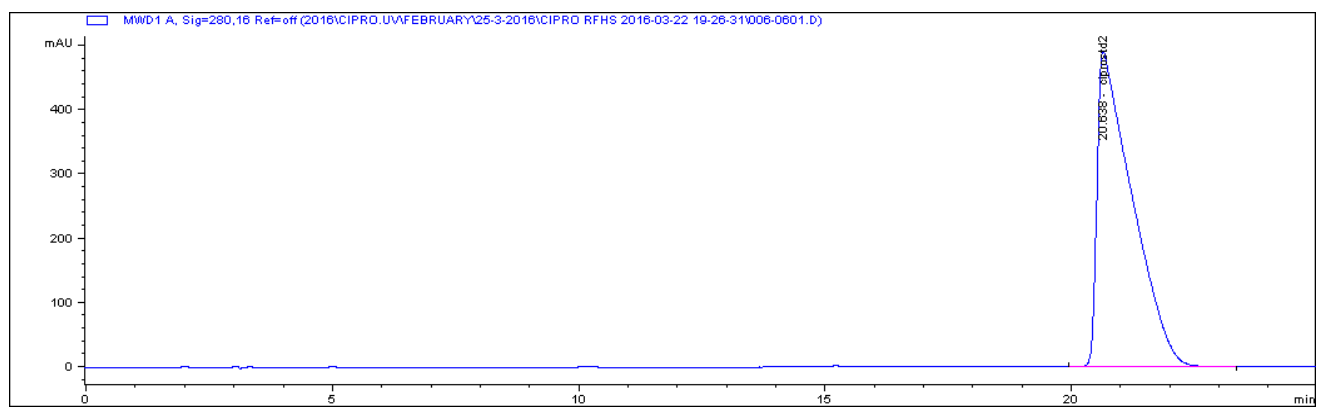

Figure (3): chromatogram of ciprofloxacin residues of chicken kidney (1 ) chicken liver (2) turkey kidney, (3) turkey liver (4)

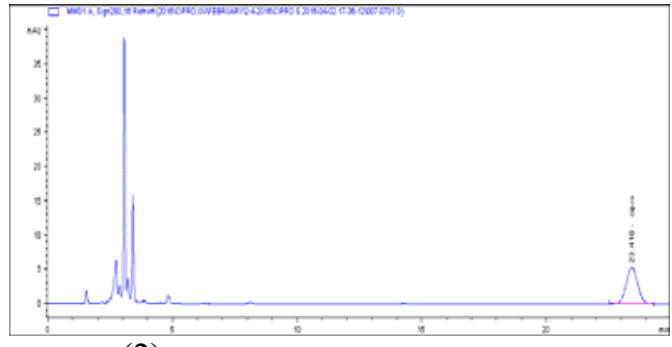

(2)

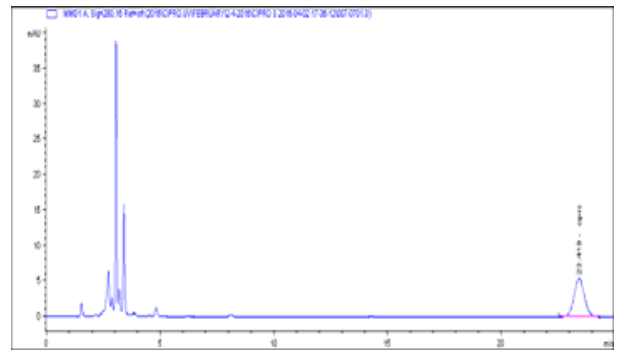

(4)

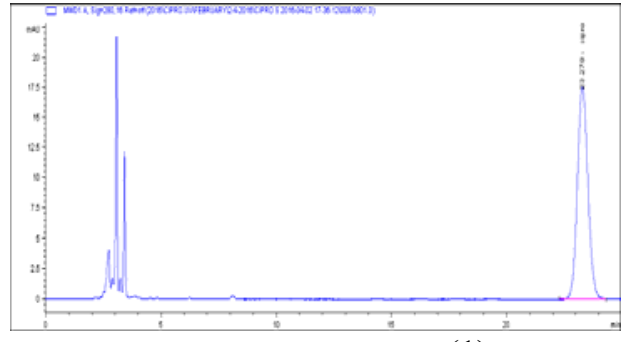

(1)

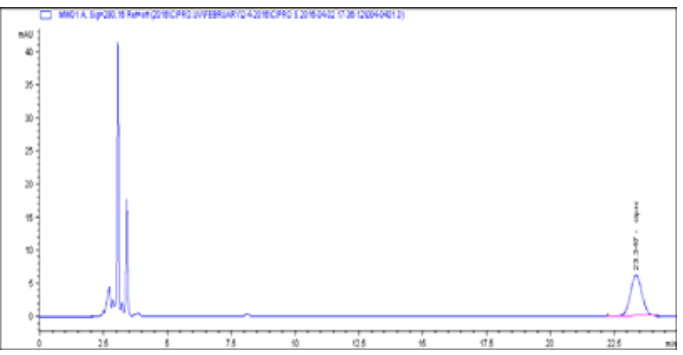

(3) 
From the point of view, results achieved in table (2) showed a significant difference among examined turkey samples. The average means were illustrated that kidney and liver samples were the harbor site of ciprofloxacin residues than breast and thigh muscles. The acceptability of turkey thigh samples was 3 of 9 samples $(33.3 \%)$ had exceeded the (MRL), while 6 of 9 samples $(66.7 \%)$ were within the permissible limit (PL). Whereas in breast. Unaccepted breast samples were 5 of 11 samples (45.5\%) had exceeded the (MRL), while 6 of 11 samples $(54.5 \%)$ were within the (PL). While in turkey liver samples 7 of 12 samples $(58.3 \%)$ were unaccepted as they exceeded the (MRL), while 5 of 12 samples $(41.7 \%)$ were within the (PL). This obtained results revealed the acceptability of kidneys samples as 8 of 12 samples (66.7\%) exceeded the (MRL), while 4 of 12 samples $(33.3 \%)$ were within the (PL).

From the obtained results in table (3) it is cleared that heat treatment processes "boiling, grilling and roasting" hadn't any effect on the degradation of ciprofloxacin residues. Only microwaving at $800 \mathrm{~W}$ for $15-20$ minutes for muscles, 3-5 minutes for liver and kidney and freezing at $-20 \mathrm{c}^{\mathrm{o}}$ for one month could degrade ciprofloxacin residues in chicken tissues to level below than (MRL) that set by EMEA, (2002) as $100 \mu \mathrm{g} / \mathrm{kg}$ in poultry muscles, $200 \mu \mathrm{g} / \mathrm{kg}$ in liver and $300 \mu \mathrm{g} / \mathrm{kg}$ in kidney.

The achieved results in table (4) it is evident that microwaving at $800 \mathrm{~W}$ for $15-20$ minutes for muscles, 3-5 minutes for liver and kidney and freezing at $-20 c^{\circ}$ for one month could degrade ciprofloxacin residues in turkey tissues to level below than (MRL) that set by EMEA, (2002) as $100 \mu \mathrm{g} / \mathrm{kg}$ in poultry muscles, $200 \mu \mathrm{g} / \mathrm{kg}$ in liver and $300 \mu \mathrm{g} / \mathrm{kg}$ in kidney. In contrast to other cooking processes "boiling, grilling and roasting " hadn't any degrading effects on ciprofloxacin residues.

\section{DISCUSSION}

The present results in table (1) were in harmony with those reported by Raphaella (2008); Silva and Hollenbach (2010) and Sarita et al. (2015) who found that liver and kidneys are the reservoir of ciprofloxacin residues. On the other words these results were higher than those obtained by Sattar et al. (2014) who detected that ciprofloxacin residues in chicken liver $44 \%$, in thigh $34 \%$ and in breast $30 \%$. These owing to the examined samples in this study may be came from farms had a haphazard's usage of ciprofloxacin antibiotic in drinking water and in mix feed. Especially before transportation to avoid emergency death of chicken. These current results were disagreed with those reported by Amjad et al. (2005) and Mestorino et al. (2011) who found that muscles had the largest rate of ciprofloxacin residues beside liver, kidney, fat and skin.

The achieved results in table (2) were in quietly similar to those obtained by Lucatello et al. (2015) and Trouchon and Lefebvre (2016) who discussed that ciprofloxacin accumulated mainly in turkeys kidney and liver. The current results were higher than those achieved by Clemente et al. (2006) and Pena et al. (2010). These elevations owing to may be turkey came from farms had a heavy wrong using of ciprofloxacin antibiotics without following withdrawal periods and Slaughtering diseased turkey emergency to avoid death.

The results in table (3) were greatly similar to those obtained by Roca et al. (2010) who stated that quinolones are very stable during thermal procedures even by heating to ultra-high temperatures had nearly no effects on degradation. On other words these results disagreed with those reported by Fathy et al. (2015) who found that ciprofloxacin residues could be degraded by heat treatment.

These results were differed with those achieved by Khan et al. (2016) that they found that ciprofloxacin residues in chicken tissues were degrade by boiling by $68.18 \%$. These results were agreed with those obtained by Lolo et al. (2006) who decided that enrofloxacin residues in chicken tissues didn't degrade by grilling. The current results were disagreed with those obtained by Fathy et al. (2015) who decided that ciprofloxacin amounts in chicken tissues could be degraded by grilling from 5999.3ppb to $1956.61 \mathrm{ppb}$.In the same lines the present results were in un acceptance with those reported by Khan et al., (2016) who found that ciprofloxacin residues in chicken tissues degrade after grilling by $33.34 \%$.The achieved results were agreed with those obtained by Lolo et al., (2006) who decided that enrofloxacin residues didn't degrade by roasting. Whereas our results were in differs with those results declared by Khan et al., (2016) who found that ciprofloxacin residues in chicken tissues could be degraded by roasting processes by $68.76 \%$. From the point of view these results were in accordance with those reported by Khan et al., (2016) who deduced that microwaving can degrade ciprofloxacin residues. Our current results were disagreed with those achieved by Javadi (2011) who revealed that highly detectable residual amount of enrofloxacin residues in 
chicken tissues were appeared after microwaving. These results were in accordance with those obtained by Aboul EL (2006) who found that ciprofloxacin residues were reduced after freezing at $-18{ }^{\circ} \mathrm{C}$ for 1 month to levels be lower than the MRL. Due to the shortage of studies about the effect of heat treatment on ciprofloxacin residues in turkey tissues. Our results in table (4) deduced that ciprofloxacin residues in turkey tissues couldn't degrade by any heat treatment processes "boiling, grilling, roasting" except microwaving and freezing. The means of raw thigh samples before microwaving were $151.7 \mu \mathrm{g} / \mathrm{kg}$, whereas after microwaving the means became $3 \mu \mathrm{g} / \mathrm{kg}$ by $\mathrm{R} \%$ (98). While after freezing for 1 month at $-20 \mathrm{c}^{\mathrm{O}}$ became $5.6 \mu \mathrm{g} / \mathrm{kg}$ by R\% (96.3). The mean of raw breast samples was $170.4 \mu \mathrm{g} / \mathrm{kg}$, became after microwaving $3.9 \mu \mathrm{g} / \mathrm{kg}$ by $\mathrm{R} \%$ (97.8), while after freezing were $6.9 \mu \mathrm{g} / \mathrm{kg}$ by R\%(96). The mean of raw liver samples was $282.48 \mu \mathrm{g} / \mathrm{kg}$ that became after microwaving $17.6 \mu \mathrm{g} / \mathrm{kg}$ by $\mathrm{R} \%$ (93.8), whereas after freezing became $15.7 \mu \mathrm{g} / \mathrm{kg}$ by $\mathrm{R} \%$ (94.4). The means of raw kidneys samples were $373.4 \mu \mathrm{g} / \mathrm{kg}$, after microwaving became $24.6 \mu \mathrm{g} / \mathrm{kg}$ by R\% (93.4). While after freezing were $23.2 \mu \mathrm{g} / \mathrm{kg}$ by $\mathrm{R} \%$ (93.8).

\section{REFERENCES}

Aboul EL, N.M., 2006. Effect of boiling and freezing on ciprofloxacin residues in chicken tissues. Assuit Vet. Med. J. 52, 111-120.

Amjad, H., Naeem, M., Iqbal, J., Khan, K., 2005. Estimation of selected residual antibiotics in poultry products available in local markets during summer. J. of the Chemical Society of Pakistan 27, 637-642

Botsoglou, N.A., Fletouris, D.J., 2001. Drug Residues in Foods, Pharmacology, Food Safety, and Analysis. Marcel Dekker, New York.

Clemente, M., Hermo, M.P., Barrón, D., Barbosa, J., 2006. Confirmatory and quantitative analysis using experimental design for the extraction and liquid chromatography-UV, liquid chromatography-mass spectrometry and liquid chromatography-mass spectrometry/mass spectrometry determination of quinolones in turkey muscle. J Chromatogr A 1135, 170-178.

European Agency for the Evaluation of Medicinal (EMEA), 1998. Committee for veterinary medicinal products, Enrofloxacin. Summary report (2). EMEA/MRL/388/98-FINAL, 16.
European Agency for the Evaluation of Medicinal (EMEA), 2002. Committee for veterinary medicinal products. Enrofloxacin. "Extension to all food producing species".Summary report (5). EMEA/MRL/820/02-final. junuary 2002.

Fathy, F.M., Ahmed, A.M., Morsi, M.K., 2015. Effect of cooking on antibiotic residues in broilers chicken meat. 2nd conference of food safety. Suez Canal university, Faculty of veterinary Medicine.

Feldman, D., Ganon, J., Haffman, R., Simpson, J., 2003. The solution for data analysis and presentation graphics. 2nd Ed., Abacus Lancripts, Inc., Berkeley, USA.

Gouvêa, R.I., Santos, F.F., Dosi, A., Quino, M.H.C., Dell Pereira, V.L., De, A.I.I., 2015. Fluoroquinolones in Industrial Poultry Production. Bacterial Resistance and Food Residues 17, 1-10.

Javadi, A., 2011. Effect of roasting, boiling and microwaving cooking method on Doxycline residues in edible tissues of poultry by microbial method. African Journal of Pharmacy and Pharmacology 5, 1034-1037.

Kameri, M., Tsutsumi, K., Kotegawa, T., Nakamura, K., Nakano, S.H., 1998. Determination of ciprofloxacin in plasma and urine by HPLC with ultraviolet detection. Clinical Chemistry 44, 12511255.

Khan, A.A., Randhawa, M.A., Butt1, M.S., Nawaz, H., 2016. impact of various processing techniques on dissipation behavior of antibiotic residues in poultry meat. Journal of food processing and preservation 40, 7682.

Lolo, M., Pedreira, S., Miranda, J.M., Vázquez, B.I., Franco, C.M., 2006. Effect of cooking on enrofloxacin residues in chicken tissue. Food Additives and Contaminants 23, 988993.

Lucatello, L., Cagnardi, P., Capolongo, F., Ferraresi, C., Bernardi, B., Montesissa, C., 2015. Development and validation of an LCeMS/MS/MS method for thequantification of fluoroquinolones in several matrices from treated turkeys. Food Control 48, 2-11.

Mestorino, N., Daniele, M., Cárdenas, M.A., Dadé, M., Errecalde, J.O., 2011. XXII Latin American Poultry Congress; 2011. Perfil residual de fosfomicinatrassu administración oral a pollosparrilleros.

Pena, A., Silva, L.J.G., Pereira, A., Meisel, L., Lino, C.M., 2010. Determination of fluoroquinolone residues in poultry muscle 
in Portugal. Anal Bioanal Chem. 397 26152621.

Posyniak , A., Zmudzki, J., Semeniuk, S., 2001. Effects of the matrix and sample preparation on the determination of fluoroquinolone residues in animal tissues. J. Chrom. A. 914, 89-94.

Raphaella, W., 2008. enrofloxacin and ciprofloxacin residues in broiler chicken post administration of enrofloxacin. Indonesian journal of animal and veterinary sciences 13, 150-154.

Roca, M., Castillo, M., Marti, P., Althaus, R.L., Molina, M.P., 2010. the effect milk processing temperatures on the presence of antimicrobial residues. J. Agric Food Chem 58, 5427-5431.

Sarita, P., Ferrari, G., Bonassa, K.P.D., Coelho, M.B., Feerriera, C.R., de Costa, H.F., Jara, J.L.P., Miguel, M.C.V., Reyes, F.G.R., Eberlin, M.N., Nogueiraa, G.P., Simas. R.C., 2015. High precision and selectivity for quantitation of enrofloxacin and ciprofloxacin in five chicken tissues using solid phase extraction and ESI LC-MS/MS for application in monitoring residues. Anal. Methods 7, 3291-3297

Sattar, S., Hassan, M.M., Islam, S.K.M.A., Alam, M., Faruk, M.S.A., Chowdhury, S., Saifuddin, A.K.M., 2014. Antibiotic residues in broiler and layer meat in Chittagong district of Bangladesh. Veterinary World 7, 738-743.

Silva, J.M.B., Hollenbach, C.B., 2010. Fluoroquinolonas x Resistência bacteriana na medicina veterinária. Arquivos do Instituto Biológico, São Paulo 77, 363-369.

Trouchon, T., Lefebvre, L., 2016. A review of enrofloxacin for veterinary use. Open Journal of Veterinary Medicine 6, 40-58.

Verdon, E., Couëdor, P., Sanders, P., AFSSALERMVD, 2004. Validation of a multiquinolone, multi-matrix, multi-species method for the determination of quinolone residues by HPLC with fluorescence detection. Afssa. French Agency for Food Safety, BP 90203 , 35302 Fougères and FRANCE Community Reference Laboratory for Antimicrobial Residues in Food from Animal Origin. 